\title{
TINGKAT KELELAHAN PENGEMUDI BUS RAPID TRANPORT (BRT) JAKARTA BERDASARKAN SWEDISH OCCUPATIONAL FATIGUE INDEX (SOFI)
}

\author{
Rida Zuraida ${ }^{1}$ \\ ${ }^{1}$ Industrial Engineering Department, Faculty of Engineering, BINUS University \\ Jl. KH. Syahdan no. 9, Palmerah, Jakarta Barat, Indonesia \\ rzuraida@binus.ac.id
}

\begin{abstract}
Fatigue is a common situation experienced by everyone, but until now a simple measuring tools universally accepted is not exist. Fatigue measurement instrument most widely used is an instrument-based questionnaire. This study used the Swedish Occupational Fatigue Index (SOFI) as one of the instrument to measure BRT driver's fatigue. The aim is to evaluate physical mental, and shift work fatigue and provide an overview of fatigue levels experienced by the driver BRT on two different shifts. Hopefully it can be used for driver fatigue management by a company. The study was conducted for two different shifts (morning and afternoon), with a total participants are 30 drivers. Results showed that motivation level of shift 2-driver is lower after they finish their work compared to shift1-driver. In shift 1, generally available time to rest, socializing and hanging out with family is longer than available time for shift 2-driver. Perception of loss of energy after work is also higher in shift 2 compared to shift 1, especially the perception of feeling exhausted. Similar results were obtained in the physical aspect and the physical exertion and physical discomfort. Therefore we can conclude the work shift has affected fatigue level experienced by the driver's BRT, and shift rotation is suggested to help the driver to recuperate.
\end{abstract}

Keywords: fatigue, driver fatigue, shift work, Swedish occupational fatigue index(SOFI)

\begin{abstract}
ABSTRAK
Kelelahan merupakan kejadian yang dirasakan dan dialami oleh seseorang, akan tetapi pengukurannya masih saja berada pada area abu-abu karena belum ada alat ukur sederhana yang disepakati secara universal. Instrumen pengukuran kelelahan yang paling banyak digunakan sampai saat ini adalah instrumen yang bersifat subjektif berbasis kuesioner. Penelitian ini menggunakan Swedish Occupational Fatigue Index (SOFI) sebagai alat ukur kelelahan subjektif bagi pengemudi BRT Jakarta, yang bertujuan untuk mengevaluasi kelelahan dari aspek fisik, mental, dan aspek kerja shift. Hasil evaluasi diharapkan dapat memberikan gambaran tingkat kelelahan yang dialami pengemudi BRT pada dua shift yang berbeda dan usulan bagi manajemen kelelahan pengemudi. Penelitian dilakukan pada pengemudi di dua shift yang berbeda (pagi dan siang), dengan total partisipan 30 pengemudi. Hasil penelitian menunjukkan bahwa perubahan tingkat motivasi sebelum bekerja dan sesudah bekerja paling banyak berkurang pada pengemudi di shift 2 dibandingkan shift 1. Pada shift 1, setelah bertugas, pengemudi memiliki waktuyang relatif panjang untuk istirahat, bersosialisasi dan berkumpul bersama keluarga dibandingkan dengan pengemudi shift 2. Persepsi kehilangan energi setelah bekerja juga lebih tinggi pada shift 2 dibandingkan dengan shift 1, terutama persepsi perasaan exhausted. Hasil yang sama diperoleh pada aspek physical exertion dan dan physical discomfort. Sehingga dapat disimpulkan shift kerja berpengaruh terhadap tinggi rendahnya kelelahan yang dialami oleh pengemudi BRT, dan rotasi shift akan membantu pengemudi dalam memulihkan diri.
\end{abstract}

Kata kunci: kelelahan, kelelahan pengemudi, shift kerja, Swedish occupational fatigue index 


\section{PENDAHULUAN}

Jakarta merupakan salah satu kota terpadat di Indonesia, bahkan di dunia, dengan jumlah penduduk 12,7 juta pada siang hari dan 9,9 juta pada malam hari (Ramadhina, 2014). Jumlah penduduk yang lebih tinggi di siang hari, berasal dari para pegawai yang tinggal di kota penyangga di sekitar Jakarta. Tingginya arus penduduk, jumlah kendaraan pribadi yang masuk setiap hari, serta pergerakan dari satu tempat ke tempat lainnya di area Jakarta, menuntut Provinsi DKI Jakarta untuk dapat menyediakan transportasi masal yang aman, terjangkau dan dapat diandalkan, serta tentu saja diharapkan dapat mengurangi kemacetan di jalanan Ibu kota.

Provinsi DKI Jakarta sejak tahun 2004 telah menyediakan Bus Rapid Transit (BRT) sebagai salah satu strategi dari pola transportasi makro (PTM) dengan tujuan meningkatkan layanan transportasi bagi masyarakat. Hingga kini BRT melayani 12 koridor atau rute layanan dengan tingkat kemacetan, panjangnya jalur rute layanan, area steril serta kepadatan penumpang yang beragam. Pengguna BRT sendiri dari tahun ke tahun semakin meningkat selain dikarenakan bertambahnya rute yang dilayani, juga pada beberapa rute BRT yang disediakan menjadi satu-satunya layanan transportasi umum yang terjangkau bagi masyarakat.

Setiap rute yang dilayani BRT memiliki keunikan dan kondisi yang berbeda-beda, antara lain karena jumlah pengguna, dalam hal ini penumpang, berbeda sehingga tingkat kepadatan penumpang pada tiap koridor Busa normal dan juga Busa sangat padat. Berdasarkan pengamatan, jalur khusus BRT yang seharusnya steril seringkali tetap dilalui oleh kendaran lain, baik roda empat maupun roda dua. Hanya pada beberapa rute dan area tertentu, jalur khusus ini benar-benar steril. Pengemudi BRT harus sangat berhati-hati terhadap para pengendara ataupun hal lain seperti orang menyeberang pada jalur khusus ini. Sehingga beban kerja yang dialami pengemudi BRT Busa jadi lebih tinggi dibandingkan pengemudi kendaraan umum lain di DKI Jakarta dan dapat mempengaruhi tingkat kelelahan yang mungkin dialami oleh pengemudi BRT.

Pada setiap rute, pelayanan BRT ditangani oleh pengemudi yang bekerja pada dua shift yang berbeda yaitu shift pagi dan siang. Pada rute tertentu, diberlakukan juga layanan hingga larut malam karena cukup banyak pekerja di DKI Jakarta yang pulang bekerja pada larut malam. Kondisi jalanan pada kedua shift tidak sama, antara lain pada tingkat kepadatan jalanan dan jumlah penumpang. Secara teori, waktu kerja (time of day) seseorang mempengaruhi tingkat kelelahan dalam bekerja (Williamson et. al., 2011). Sehingga perbedaan ini dapat saja mempengaruhi tingkat kelelahan pengemudi BRT pada masing-masing shift, selain kondisi yang telah disebutkan pada paragraf sebelumnya.

Pembahasan mengenai tingkat kelelahan pengemudi BRT di DKI Jakarta masih sangat minim dan pembahasan dalam paper ini menjadi penting dikarenakan kondisi kerja pengemudi yang kurang mendukung dapat menimbulkan kelelahan kerja kronis yang berdampak pada penurunan produktivitas di masa yang akan datang. Pengaruh shift kerja dan beban kerja yang dialami pengemudi di masingmasing shift merupakan kajian yang perlu dilakukan. Dari total layanan BRT di seluruh area Jakarta adalah 12 rute, penelitian tingkat kelelahan pada pengemudi BRT pada paper ini baru didasarkan pada kondisi di salah satu rute layanan yang terpadat.

Metode pengumpulan data menggunakan metoda langsung dengan alat ukur sebuah kuesioner yaitu Swedish Occupational Fatigue Index (SOFI) yang menggunakan lima dimensi kelelahan dengan 25 item test pertanyan. Diharapkan dengan diperolehnya evaluasi tingkat kelelahan pengemudi BRT di kedua shift yang berbeda, dapat menjadi masukan bagi pengelola mengenai pengaturan ataupun pergantian shift kerja untuk meminimalkan kelelahan pengemudi dalam jangka panjang sebagai bagian dari manajemen kelelahan di perusahaan operator BRT. 


\section{Studi Pustaka}

Kelelahan atau fatigue masih didefinisikan secara berlainan oleh peneliti (Horrey et. al., 2011; Williamson et. al., 2011). Belum ada kesepakatan bersama mengenai definisi operasional kelelahan untuk kepentingan keilmuan dan aplikasi pada bidang industri, sehingga banyak perdebatan mengenai hal tersebut. Grandjean dan Kroemer (1997) menyatakan bahwa kelelahan adalah suatu kondisi dimana terjadi penurunan dalam efisiensi seseorang dalam bekerja dan munculnya keengganan untuk berusaha. Lal (2001) kemudian mengelompokkan kelelahan menjadi dua, yaitu kelelahan fisik dan mental. Kelelahan fisik disebabkan oleh beban kerja yang terjadi pada otot, sedangkan kelelahan mental lebih dipengaruhi oleh beban psikologis.

Fatigue masih merupakan topik yang dianggap penting dalam pembahasan mengenai keselamatan baik keselamatan di tempat kerja maupun di area transportasi (Noy et. al., 2011; Willamson et. al., 2011). Pendefinisian peneliti dalam penelitian mengenai fatigue memiliki perbedaaan dan juga kesamaan dalam beberapa hal. Cameron (1971) mendefinisikan fatigue (khususnya mental fatigue) sebagai respon dari stress (tekanan atau beban) yang terjadi sepanjang suatu periode waktu yang berdampak pada performa pengerjaan tugas. Saito (1999) dalam paper-nya mencoba menyederhanakan definisi kelelahan menjadi perasaan lelah yang diakibatkan oleh berlebihnya pekerjaan mental dan fisik yang berdampak pada penurunan fungsi atau kemampuan manusia. Sedangkan Dawson et. al. (2013) dalam paper-nya mengenai teknologi untuk mendeteksi fatigue, mendefinisikan fatigue sebagai kantuk yang dihasilkan dari proses neurobiologis yang mengatur dorongan seseorang untuk tidur.

Kelelahan fisik adalah kelelahan yang disebabkan oleh pembebanan yang berlebih pada otot, karena kontraksi otot merupakan syarat utama untuk menjalankan kerja fisik (Lal dan Craigh, 2007). Sutalaksana et. al. (2006) menjelaskan bahwa kelelahan fisiologis adalah kelelahan yang timbul karena ada perubahan-perubahan faali dalam tubuh. Pada prinsipnya terdapat lima macam mekanisme yang dijalankan tubuh, yaitu: sistem pernapasan, sistem peredaran darah, sistem pencernaan, sistem otot dan sistem saraf. Kerja fisik yang kontinu berpengaruh terhadap mekanisme yang dijalankan oleh tubuh tersebut.

Grandjean dan Kroemer (1997) menjelaskan bahwa dalam proses terjadinya kelelahan fisik, terdapat beberapa tahapan. Ketika otot berkontaksi melebihi 15\% dari MVC (maximal voluntary contraction), aliran darah yang melalui otot secara otomatis berkurang sebagai respon terhadap meningkatnya tekanan darah sistol. Minimnya aliran darah yang masuk, membuat ion potasium terakumulasi dalam di dalam cairan ekstraselular. Bila digabungkan akumulasi fosfat (hasil degradasi adenosin tripospat atau ATP) maka bahan kimia ini akan mengganggu jalannya sistem saraf dan kontraksi jaringan otot. Kondisi inilah yang menyebabkan rasa lelah secara fisik.

Kelelahan mental adalah proses kumulatif dan bertahap yang berasosiasi dengan berkurangnya efisiensi, kemampuan, kewaspadaan, dan performansi mental (Lal dan Craig, 2007). Gejala utama dari kelelahan mental adalah munculnya sensasi kelesuan. Saat merasa lelah aktivitas seseorang akan terhambat, tidak ada keinginan untuk melakukan usaha fisik atau mental, dan muncul perasaan berat dan mengantuk. Kelelahan merupakan respon alamiah tubuh manusia untuk menjaga dari kerja yang berlebih. Ashberg (1998) menjelaskan bahwa kelelahan mental bukan hanya terjadi karena kelebihan beban tetapi dapat juga disebabkan oleh kekurangan beban. Kelebihan beban mental secara kualitatif adalah melakukan pekerjaan yang terlalu rumit dan kompleks, sedangkan secara kuantitatif diartikan sebagai kelelahan yang terjadi karena waktu bekerja yang terlalu lama atau terlalu sering. Kekurangan beban, menurut Ashberg (1998) disebabkan oleh munculnya kebosanan akibat pekerjaan yang terlalu monoton. Berdasarkan penelitian terdahulu, kelelahan yang terjadi pada pengemudi berdurasi panjang cenderung lebih banyak dipengaruhi oleh kelelahan mental. 
Pada dasarnya kelelahan dapat diukur berdasarkan symptom yang terlihat ataupun yang dirasakan, atau diukur berdasarkan kondisi biomechanical tubuh seseorang. Saito (1999) membagi cara pengukuran kelelahan menjadi: (1) Tes secara psikologi seperti (a) the blocking test, (b) Kraepelin test, (c) dot counting method, (d) measurement of perception time, (e) Roken amefuri erasion test, and (f) anticipation reaction of speed, dan lain-lain. (2) Neurophysiological tests, (a) electroencephalography, (b) sensory evoked response, (c) reaction time, (d) galvanic skin reflex, (e) aesthesiometry, (f) measurement of flicker fusion frequency, $(\mathrm{g})$ target aiming function test, $(\mathrm{h})$ eye movement, (i) visual tracing reaction test, dan lain-lain. (3) Indeks biochemical, (a) urinary excretion (b) eosinophilic leucocytes, total gravity of blood, hemoglobin content, serum proteins, blood sugar, dan lain-lain. (4) Tes fisiologi, (a) muscular strength, (b) respiratory and circulatory functions, (c) heart rate, (d) near point distance, dan lain-lain, serta autonomic nervous function tests : (a) adrenaline test, (b) atropine test, (c) mecholyl test, (d) cold pressor test, (e) Czermak test, dan lain-lain.

Metode atau teknik pengukuran yang disebutkan di atas, memiliki kelebihan dan kekurangan masing-masing baik akurasi, kemudahan operasional, kemudahan pengolahan hasilnya, biaya yang harus dikeluarkan, interpretasi hasil pengukuran dan lain-lain. Kelelahan juga dapat diukur dengan metoda subjektif yang relatif cepat hasilnya dan tidak memerlukan waktu dan biaya yang besar, serta relatif mudah dalam mengintrepretasikan hasilnya. Salah satu instrument subjektif kelelahan yang banyak digunakan adalah Swedish Occupational Fatigue Index (SOFI). Instrumen ini merupakan instrumen pengukuran kelelahan dan kantuk yang pertama kali dikembangkan oleh Ahsberg (1998). SOFI memiliki lima dimensi pengukuran yaitu lack of energy, physical exertion, physical discomfort, lack of motivation dan sleepiness. Kelima dimensi ini merupakan penjabaran lebih lanjut dari kelelahan fisik (physical exertion dan physical discomfort) dan kelelahan mental (lack of motivation dan sleepiness). Dimensi lack of energy mewakili kualitas dari kelelahan yang dirasakan secara umum oleh subjek. Gambar dibawah ini adalah model kelelahan dan kantuk berdasarkan SOFI.

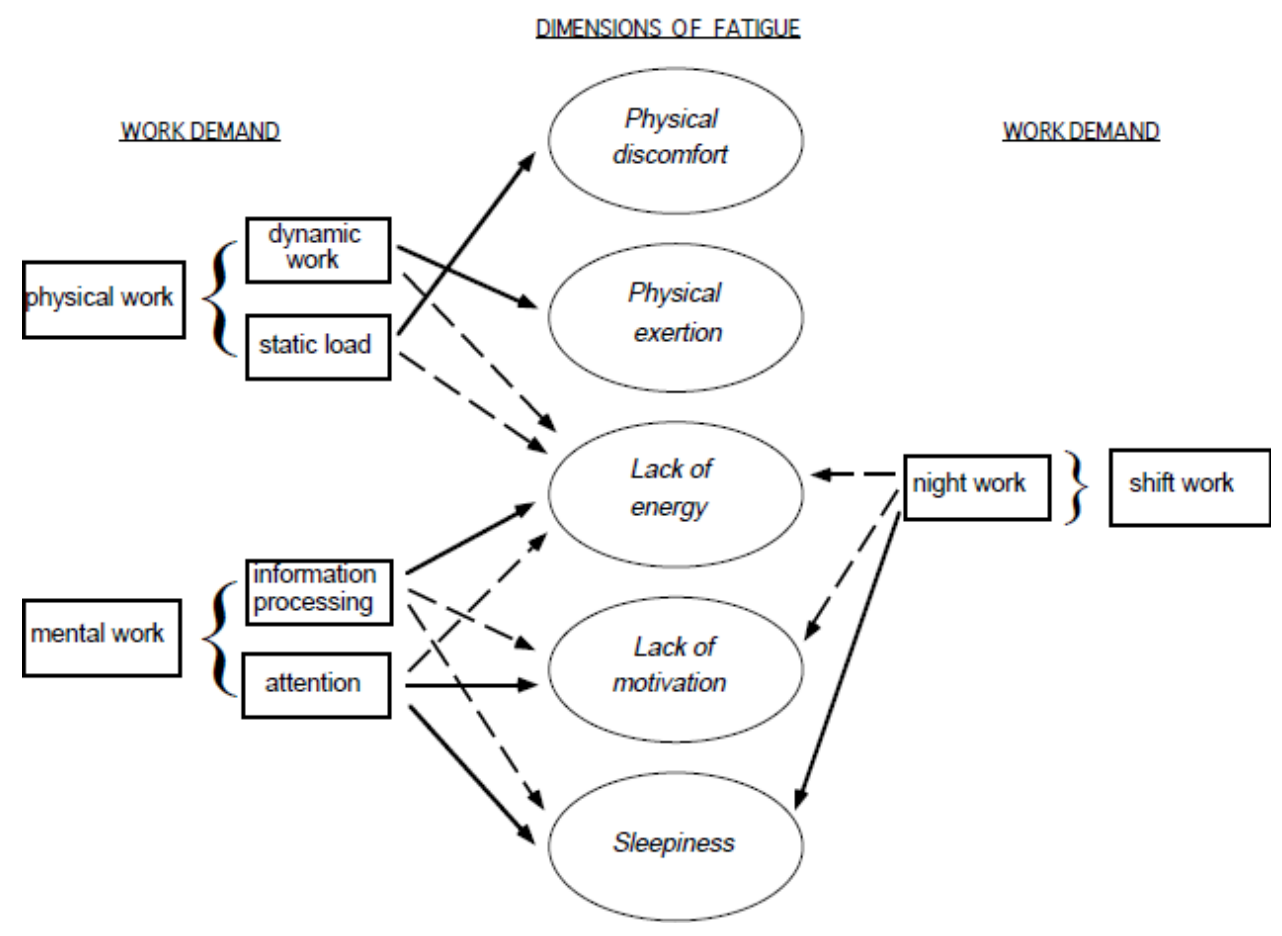

Gambar 1 Dimensi Fatigue SOFI (Ahsberg, 1998) 
Beban kerja dapat berasal faktor fisik, mental, dan adanya shift kerja. Ketiga faktor ini membentuk lima dimensi dari kelelahan yang dijabarkan dalam 25 poin pernyataan. Tiap subjek diminta untuk menilai kondisi diri secara subjektif mulai dari skala 0 hingga 6 . Skala 0 berarti tidak terasa dan skala 6 berarti pernyataan tersebut sangat dirasakan dan sesuai dengan kondisi subjek.

Tabel 1 Poin pernyataan SOFI

\begin{tabular}{|c|c|c|}
\hline No & Dimensi & Poin pernyataan (skala 0-6) \\
\hline 1 & Lack of energy & $\begin{array}{l}\text { Overworked } \\
\text { Worn out } \\
\text { Exhausted } \\
\text { Spent } \\
\text { Drained }\end{array}$ \\
\hline 2 & Physical exertion & $\begin{array}{l}\text { Sweaty } \\
\text { Breathing heavily } \\
\text { Palpitations } \\
\text { Warm } \\
\text { Out of breath }\end{array}$ \\
\hline 3 & Physical discomfort & $\begin{array}{l}\text { Tense muscles } \\
\text { Stiff joints } \\
\text { Numbness } \\
\text { Hurting } \\
\text { Aching }\end{array}$ \\
\hline 4 & Lack of motivation & $\begin{array}{l}\text { Uninterested } \\
\text { Passive } \\
\text { Listless } \\
\text { Indifferent } \\
\text { Lack of concern }\end{array}$ \\
\hline 5 & Sleepiness & $\begin{array}{l}\text { Sleepy } \\
\text { Falling asleep } \\
\text { Drowsy } \\
\text { Yawning } \\
\text { Lazy }\end{array}$ \\
\hline
\end{tabular}

\section{METODE}

Pelaksanaan penelitian dilakukan beberapa tahap dan data yang dikumpulkan pada setiap tahap terdiri data sekunder dan data primer. Adapun data sekunder terdiri data umum pengemudi sebagai responden, regulasi umum bagi pengemudi termasuk jam kerja pengemudi. Data umum lain yang telah ada baik dari penelitian yang telah dilakukan berupa data waktu kedatangan bus, data waktu kedatangan bus, serta lama waktu perjalanan dari satu halte ke halte lainnya. Sedangkan data primer adalah data persepsi kelelahan pengemudi berdasarkan dimensi SOFI. Pengumpulan dilakukan dengan melakukan wawancara langsung dengan pengemudi BRT. 
Berikut adalah langkah-langkah penelitian yang telah dilakukan:

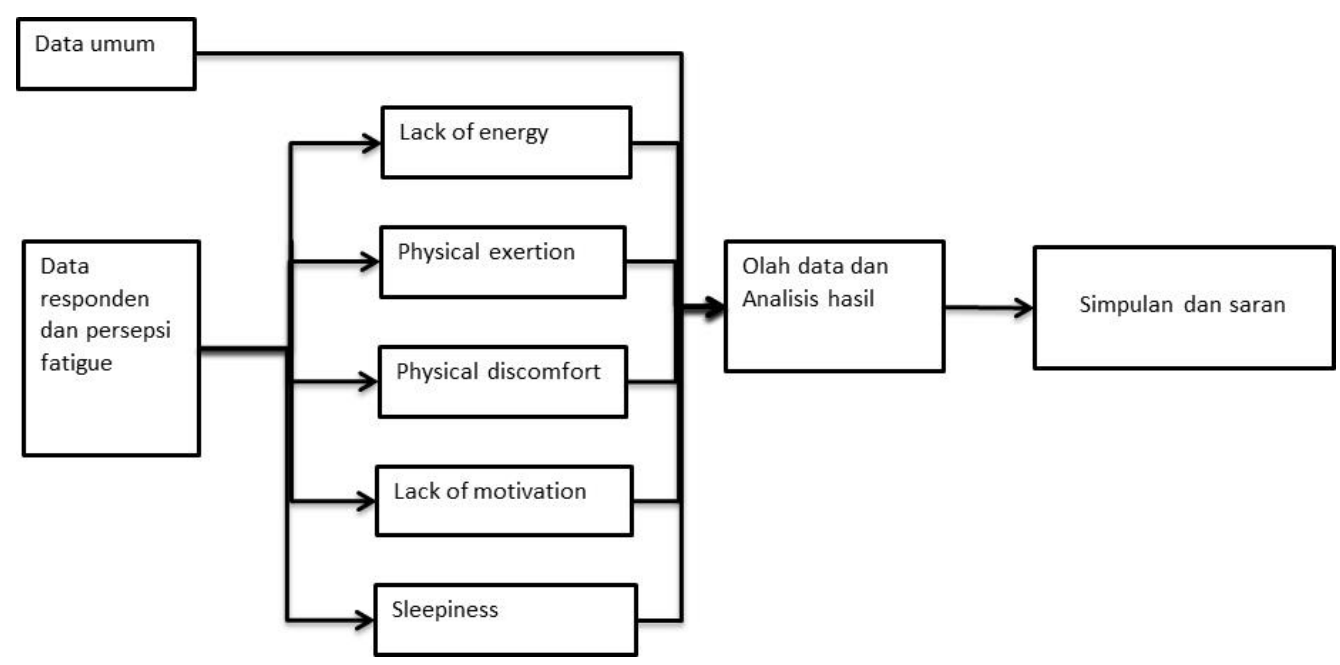

Gambar 2 Langkah-langkah penelitian

Pada proses pengumpulan data, pengemudi yang menjadi responden adalah pengemudi pada shift 1 dan pada shift 2. Pengemudi shift 1 memulai bekerja pada pukul 5 pagi hingga selesai sedangkan shift 2 mulai bekerja pada pukul 12 siang hingga selesai. Pengemudi sebagai responden diberi penjelasan mengenai data apa saja yang akan diminta, serta responden diminta mengisi kesediaan untuk menjadi responden jika bersedia. Selanjutnya pengemudi sebagai responden akan diminta untuk memberikan skor 0 sampai 6 atas apa yang mereka rasakan seusai dengan pertanyaan yang disampaikan di awal sebelum bertugas, dan di akhir sesudah bertugas. Pertanyaan yang diajukan merupakan pertanyaan tingkat kelelahan menggunakan lima (5) dimensi Swedish Occupational Fatigue Index (SOFI). Data ini kemudian diolah untuk menentukan tingkat kelelahan berdasarkan kelima dimensi tersebut. Tingkat kelelahan antar pengemudi yang berbeda shift dilakukan untuk melihat apakah waktu kerja memiliki dampak terhadap kondisi kelelahan pengemudi. Hasil pengolahan dan pengujian, selanjutnya dianalisis untuk memperoleh simpulan mengenai tingkat kelelahan pengemudi BRT di rute terpadat dari 12 rute yang tersedia.

\section{HASIL DAN PEMBAHASAN}

Sebelum melakukan pengukuran tingkat kelelahan pengemudi BRT, dilakukan dahulu pengamatan di lapangan serta pengumpulan data mengenai kondisi pelayanan BRT pada 12 rute yang dilayani. Data yang dikumpulkan berupa jumlah penumpang dalam satu tahun, jumlah halte pemberhentian pada setiap rute, jarak rute dari halte awal hingga halte akhir, serta rata-rata jarak antar halte. Setelah data diperoleh, maka ditentukan pengamatan dilakukan di Koridor I, sebagai Pengamatan dilakukan pada 24 pengemudi BRT yang memiliki jumlah penumpang paling tinggi. Berikut adalah data jumlah penduduk pada 12 rute layanan : 
Tabel 2 Jumlah Penumpang, Halte, Jarak Rute, dan Jarak Antar Halte per Koridor

\begin{tabular}{llcccc}
\hline \multicolumn{1}{c}{ Koridor } & \multicolumn{1}{c}{ Rute } & $\begin{array}{c}\text { Jumlah } \\
\text { penumpang } \\
\text { (orang) }\end{array}$ & $\begin{array}{c}\text { Jumlah } \\
\text { halte }\end{array}$ & $\begin{array}{c}\text { Jarak Rute } \\
(\mathbf{m})\end{array}$ & $\begin{array}{c}\text { Jarak antar halte } \\
(\mathbf{m})\end{array}$ \\
\hline Koridor I & Blok M - Kota & 23.792 .069 & 20 & 12,9 & \pm 650 \\
Koridor II & Pulo Gadung - Harmoni & 8.821 .192 & 32 & 14,3 & $700-800$ \\
Koridor III & Harmoni - Kalideres & 10.831 .473 & 16 & 14,0 & $700-800$ \\
Koridor IV & Pulo Gadung - Dukuh Atas & 7.282 .254 & 17 & 11,5 & $400-1600$ \\
Koridor V & Kp Melayu - Ancol & 11.436 .445 & 18 & 13,5 & $400-2250$ \\
Koridor VI & Ragunan - Kuningan & 9.090 .588 & 20 & 13,3 & $400-1000$ \\
Koridor VII & Kp Rambutan - Kp Melayu & 10.681 .357 & 14 & 12,8 & $500-1500$ \\
Koridor VIII & Lebak Bulus - Harmoni & 8.516 .995 & 18 & 26,0 & $500-1500$ \\
Koridor IX & Pinang Ranti - Pluit & 14.352 .556 & 26 & 28,9 & $500-1500$ \\
Koridor X & Cililitan - Tanjung Priok & 3.895 .295 & 22 & 19,4 & $500-1000$ \\
Koridor XI & Kp Melayu - Pulo Gebang & 2.560 .645 & 15 & 11,8 & $300-1000$ \\
\hline
\end{tabular}

Sumber : http://www.transjakarta.co.id/publikasi.php?q=1pXPwtjR4g==

Pengumpulan data dilakukan dengan menggunakan kuesioner yang berisi pertanyaan mengenai tingkat kelelahan berdasarkan 5 dimensi SOFI. Kuesioner diisi dengan dipandu oleh pengumpul data, untuk memastikan bahwa pertanyaan yang disampaikan pada kuesioner dipahami sehingga data yang diperoleh sesuai dengan harapan. Pengemudi TransJakarta diminta untuk memberikan penilaian tingkat kelelahan secara subjektif berdasarkan lima dimensi SOFI, yaitu pada awal sebelum bertugas, dan sesudah bertugas. Selisih nilai SOFI positif menunjukkan kelelahan bertambah pada dimensi tersebut, sedangkan nilai negatif menunjukkan kelelahan berkurang pada dimensi tersebut. Tabel 3, berisi nilai selisih untuk setiap pernyataan pada 5 dimensi SOFI, untuk setiap shift kerja yang diamati, dan nilai persepsi sebelum bertugas.
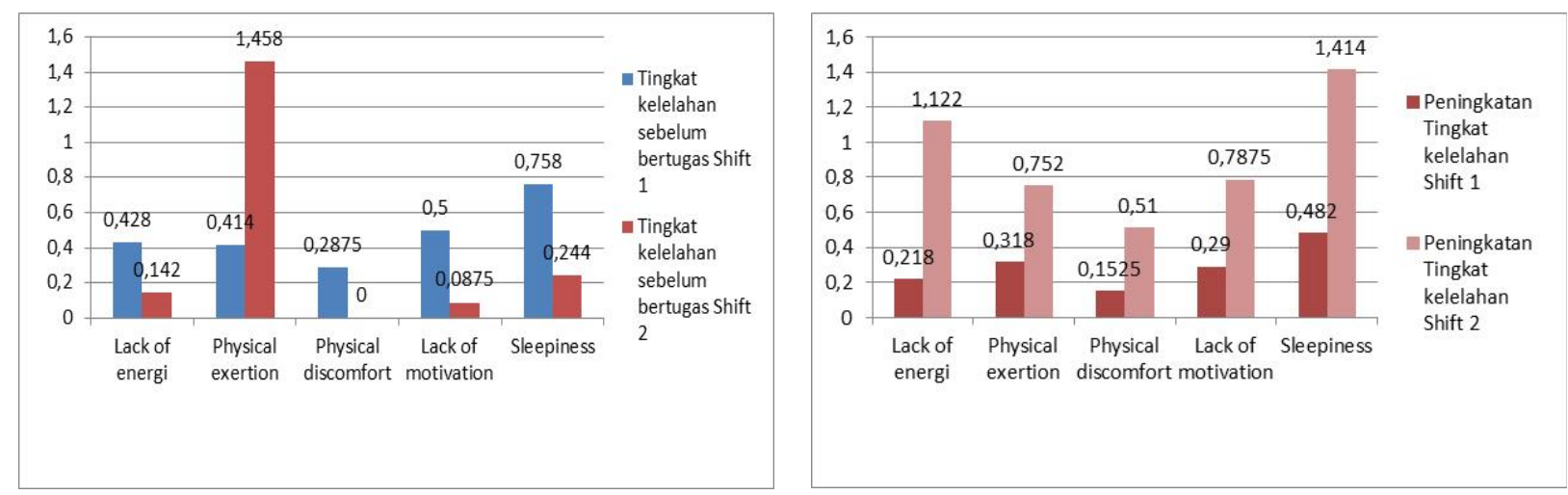

Gambar 1 Tingkat Kelelahan Pengemudi BRT dan Besarnya Peningkatan setelah Bekerja

Berdasarkan data yang dikumpulkan, terlihat bahwa pekerjaan mengemudi di Transjakarta merupakan pekerjaan yang menuntut konsentrasi yang tinggi, dan menimbulkan kelelahanbaik mental maupun fisik. Hal ini terlihat dari nilai selisih pada shift 1 dan 2 yang bernilai positif artinya terjadi penambahan tingkat kelelahan yang dirasakan oleh pengemudi. Berdasrkan grafik di atas, nilai kelelahan pengemudi sebelum bertugas pada shift1 lebih tinggi dibandingkan dengan shift 2, kecuali untuk kategori physical exertion. Akan tetapi penambahan tingkat kelelahan setelah bekerja pada shift 
2, lebih tinggi dibandingkan pengemudi yang bekerja di shift 1 untuk semua kategori. Penyebabnya adalah pengemudi shift 1, memulai kerja sangat awal, yaitu sudah harus bersiap-siap sejak pukul 4 pagi atau bahkan lebih pagi lagi, selain itu, tingkat kemacetan pada shift 1 lebih tinggi dibandingkan dengan shift 2 karena bertepatan dengan jam masuk sekolah serta jam masuk kerja para pekerja di pagi hari.

Perubahan tingkat motivasi merupakan perubahan yang paling kecil dibandingkan dengan dimensi lainnya, dan perubahan tingkat motivasi antara sebelum bekerja dan sesudah bekerja paling sedikit terjadi pada pengemudi shift 1 dibandingkan dengan shift 2. Diperkirakan hal ini didorong oleh kondisi bahwa pengemudi yang bekerja pada shift 1, merasa memiliki waktu yang cukup banyak untuk istirahat setelah bekerja, bersosialisasi dan berkumpul bersama keluarga, karena selesai bertugas di siang hari. Sebaliknya, pengemudi shift 2 hanya memiliki sisa waktu untuk beraktivitas lain yang lebih sedikit karena selesai bertugas di malam hari.

Perubahan persepsi kehilangan energi, dirasakan paling banyak pada shift 2 dibandingkan dengan shift 1terutama untuk perasaan exhausted atau merasa lelah. Faktor yang sama yang dijabarkan pada paragraf sebelumnya bisa jadi menjadi penyebabnya. Perubahan dimensi physical exertion dan physical discomfort, lebih tinggi pada pengemudi shfit 2 dibandingkan dengan shift 1, yang menunjukkan bahwa physical exertion dan physical discomfort pengemudi shift 2 lebih tinggi dibandingkan dengan shift 1 .

Penambahan tingkat kantuk, paling banyak dirasakan oleh pengemudi yang bertugas di shift 2 dibandingkan dengan shift 1, selain dorongan homeostatis untuk istirahat antara pukul 2 sampai pukul 4, pengemudi shift 2 sudah terjaga atau bangun di pagi hari meskipun baru memulai shift-nya di siang hari. Artinya, lamanya terjaga kurang lebih tidak jauh berbeda dengan pengemudi pada shift 1 , tetapi saat pengemudi shift 1 sudah bisa beristirahat, pengemudi shift 2 sedang bertugas.

Secara keseluruhan, pada setiap dimensi kelelehan SOFI, pengemudi shift 1 mengalami tingkat kelelahan lebih tinggi dibandingkan dengan shift 2 di awal bertugas, tetapi penambahan tingkat kelelahannya setelah bertugas relatif kecil. Sedangkan pengemudi shift 2, menunjukkan penambahan tingkat kelelahan yang jauh lebih tinggi untuk kelima dimensi SOFI dibandingkan dengan shift 1. Selain itu, rata-rata tingkat kelelahan di awal maupun di akhir bertugas baik untuk shift 1 dan 2, maksimum berada pada skala 4 dari skala 0 sampai 6 . Hal ini menunjukkan, tingkat kelelahan masih dapat dikelola dan sistem shift yang sekarang masih dapat mengakomodir kebutuhan istirahat pengemudi. Hasil penelitian ini juga mengkonfirmasi bahwa shift kerja memiliki pengaruh besar terhadap tingkat kelelahan pada kelima dimensi SOFI, yaitu lack of energy, physical exertion, physical discomfort, motivation dan sleepiness.

\section{SIMPULAN}

Berdasarkan hasil pengumpulan data menggunakan metoda SOFI, maka terlihat bawa pekerjaan pengemudi merupakan pekerjaan yang menimbulkan kelelahan fisik dan mental, dengan pekerjaan pada shift 2 dipersepsikan lebih berat dibandingkan dengan shift 1. Persepsi ini ditunjukkan oleh nilai rata-rata selisih dan rata-rata nilai SOFI pengemudi di kedua shift sehingga mengkonfirmasi bahwa shift kerja mempengaruhi tingkat kelelahan seseorang dan shift di awal hari lebih kecil dampaknya terhadap tingkat kelelahan akibat kerja dibandingkan dengan shift siang.

Mengingat kelelahan merupakan fenomena yang kompleks, untuk merumuskan perbaikan sistem kerja yang dapat mengurangi risiko kelelahan dalam jangka panjang dan meningkatkan kenyamanan pengemudi, maka masih diperlukan pengukuran dengan berbagai metoda lainnya, untuk 
mengkonfirmasi tingkat kelelahan dan ketidaknyamanan yang dialami. Berdasarkan nilai SOFI untuk setiap dimensi kelelahan, nilai persepsi kelelahan pengemudi masih berada pada kondisi dapat diterima. perbaikan tetap disarankan, untuk menghindari dampak kelelahan yang kronis di masa yang akan datang. Kajian lanjutan mengenai dampak dari shift kerja dan rotasi kerja disarankan untuk dilakukan dengan memperhatikan penggantian shift secara teratur untuk data dalam meningkatkan kesempatan pengemudi memulihkan diri dan beristirahat.

\section{DAFTAR PUSTAKA}

Agus. (2010). Bus Transjakarta Semakin Diminati di Usia ke-6. Berita Portal Resmi Provinsi DKI Jakarta. Diakses pada 23 April 2013, dari Jakarta.go.id: http://www.jakarta.go.id/v2/news/2010/01/Bus-Transjakarta-Semakin-Diminati-di-Usia-ke6\#.VVgPF5NG5Kc

Ahsberg, E. (1998). Perceived Fatigue Related to Work. National Institute for Working Life.

Cameron C. (1971). Fatigue Problem in Modern Industry. Ergonomics, 14(6): 713-720

Dawson, D., Searle, A. K., Paterson, J. L. (2013). Look before you (s)leep: Evaluating the use of fatigue detection within a fatigue risk management system for the road transport industry. Sleep medicine, $1(12)$

Granjean E., Kroemer K. H. E. (1997). Fitting The Task To The Human, Fifth Edition: A Textbook Of Occupational Ergonomics. CRC Pers Yalor and Francis Group

Health and Safety Professionals Alliance. (2012). The Core Body of Knowledge for Generalist OHS Professionals. Tullamarine. VIC: Safety Institute of Australia.

Horrey, W. J., Noy Y. I., Folkard, S., Stephen, M. P., Howarth H. D., Courtney, T. K. (2011). Research Needs and Opportunities for Reducing the Adverse Safety Consequences of Fatigue. Accident Analysis and Prevention, 43: 591-594.

Lal, S. K., Craig, A. (2001). A Critical Review of Psychophysiology of Driver's Fatigue. Biological Psysiology, 55: 173-194.

Lal, S. K., Craig, A. (2007). Realibility of Measuring Brain Activity to Detect Driver Fatigue in Profesional Drivers. Sidney: University of Techonology Broadway.

Noy, Y. I., Horrey, W. J., Popkin S. M., Folkard, S., Howarth, H. D., Courtney, T. K. (2011). Future Directions in Fatigue and Safety Research. Accident Analysis and Prevention, 43: 495-497.

Ramadhina, F. (2014). Berapa juta jumlah penduduk Jakarta saat ini. Merdeka.com. Diakses pada 20 November 2014, dari http://www.merdeka.com/peristiwa/berapa-juta-jumlah-pendudukjakarta-saat-ini.html

Saito, K. (1999). Measurement of Fatigue in Industries. Industrial Health, 37: 134-142.

Sutalaksana, I. Z. (2006). Teknik Perancangan Sistem Kerja. Bandung: ITB

Williamson, A., Lombardi, D. A., Folkard, S., Stuts, J., Courtney, T. K., Connor, J. L, (2011), The Link Between Fatigue and Safety. Accident Analysis and Prevention, 43: 498-515. 